\title{
THE ESTABLISHMENT OF ASEPTIC CULTURES AND MULTIPLE SHOOT INDUCTION OF OLIVE (Olea europaea) cv.1
}

\author{
RU SHEN WONG ${ }^{1}$, HONG XUAN CHAI $^{1}$, SREERAMANAN SUBRAMANIAM ${ }^{1}$ \\ and BEE LYNN CHEW ${ }^{1 *}$ \\ ${ }^{1}$ School of Biological Sciences, Universiti Sains Malaysia, 11800 Penang, Malaysia \\ *E-mail: beelynnchew@usm.my
}

Accepted 29 April 2021, Published online 20 May 2021

\begin{abstract}
Olea europaea or the olive plant is from the family of Oleaceae and has been cultivated for its fruits that are highly nutritious, capable of reducing risks of cardiovascular diseases and to prevent cancer. The current propagation technique of olive plants in Malaysia relies on conventional methods that are less efficient in producing good quality plant stocks. Plant tissue culture offers an alternative to multiply plants from novel mother plants and is commonly applied in the propagation of various crops. This study aims to establish sterile cultures and to induce multiple shoots from Olea europaea cv.1 as a preliminary study to micropropagate olive plants for commercial farms in Malaysia. Nodal explants were surfaced sterilised with ethanol and Clorox $^{\odot}$ at different durations followed by treatments in MS media supplemented with different concentrations of Zeatin and BAP. Nodal explants surface sterilised with $70 \%$ (v/v) ethanol for 2 min and 30\% (v/v) Clorox $^{\odot}$ for 8 min produced sterile explants with the survival rate of $85 \%$. MS media supplemented 5.0 mg/L BAP was optimal for shoot induction $(2.10 \pm 0.31$ shoots per explant) and shoot elongation $(6.50 \pm 1.17 \mathrm{~mm})$. The current study serves as preliminary assessment for the establishment of local olive cultures.
\end{abstract}

Key words: 6-Benzylaminopurine, micropropagation, nodal explants, olive, zeatin

\section{INTRODUCTION}

The olive tree (Olea europaea), belonging to the Oleaceae family, is one of the earliest fruiting plants that co-existed with mankind since the Bronze Age. It is estimated that there are at least 800 million olive trees globally with the majority $(95 \%)$ of the world's olive orchards located in the Mediterranean basin (Fabbri et al., 2004). Due to the high annual production of olive (approximately 10 million tonnes), the olive crop has been identified as a great source of income for many producing countries (Lambardi \& Rugini, 2003; Fabbri et al., 2004). The olive tree is an evergreen, woody plant which can grow up to 15 meters in height. The leaves are ovate-oblong in shape and the leaves grow in the opposite direction (Besnard et al., 2002). The olive flowers are usually small, creamy white and grow on the axil of each leaf (Wiesman, 2009). The olive tree is also an ancient plant that is documented in various classical texts, indicating its significance to several religions and cultures. The olive is mentioned together with the fig in Surah 95 of the Quran indicating its significance to the Muslim community and was acknowledged by Prophet Muhammad for its health benefits (Attum et al., 2019).

The olive fruit is a drupe, containing an exocarp, a fleshy mesocarp and an endocarp that is unpleasant if consumed unprocessed without the removal of its bitterness associated with the presence of oleuropein (Uylaşer \& Yildiz, 2014). Olive oil, extracted from the fruit, is best-known for its health benefits particularly in lowering risks of cardiovascular diseases, prevention of cancer and is essentially high in antioxidants, antimicrobial properties and also a skin protector against UV damage (Visioli et al., 2002; Tripoli et al., 2005; Visioli et al., 2006; Haris, 2010; Schwingshackl \& Hoffmann, 2014). Furthermore, oleocanthal, a minor phenolic constituent found in olive oil, was proven to possess anti-inflammatory properties that inhibits the cyclooxygenase enzymes COX-1 and COX-2 in preventing irritation of the sensory neurons within the upper airways (Beauchamp et al., 2005; Peyrot des Gachons et al., 2011).

* To whom correspondence should be addressed. 
The global rising demands of healthy olive plant stocks for cultivation had led to the mass propagation via plant tissue culture. The selection of explants with desirable oil qualities and optimal growth in different geographical localities are important factors to be considered as olive plants are susceptible to a range of pests, diseases, and insects. Most reported studies utilize shoot tip and nodal segments as explants for culture using different types of growth media and plant growth regulators to induce multiple shoots from olive explants (Bhatia, 2015). Growth media such as the Olive Media (OM) was specially developed for olive and the supplementation of plant growth regulators such as zeatin, BAP, and TDZ was previously utilised to stimulate shoot development and multiplication (Rugini, 1981; Rugini, 1984; GarcíaFérriz et al., 2002; Binet et al., 2007; Ali et al., 2009).

The olive plant is not native to Malaysia and therefore studies on the cultivation of olive in the local farms are not yet documented. Moreover, olive cultivation in Malaysia is at its infancy and has not reached the commercial level for mass cultivation regardless the high demand for plant stocks for farm establishments. The current conventional methods for olive plants via cuttings and grafting are very much ineffective due to the low survival rate and the inability to produce viable roots, indirectly reducing the availability of plant stocks for commercialization. Plant tissue culture, on the other hand, has been proven as an efficient tool in plant propagation of various commercial crops, resembling the qualities of the mother plants. This technology functions as an alternative in the mass propagation of olive plant stocks that can be further grown in the local farms where plant stocks and harvesting period can be standardised for commercial cultivation and production of olive based products. The current study aims to establish sterile explants of olive and to induce multiple shoots using cytokinin such as BAP and zeatin for the micropropagation of olive in Malaysia. This study, in future, will facilitate mass propagation attempts particularly to produce highquality olive plant stocks for commercial farms. This opportunity would be beneficial to the Malaysian economy in the production olive as a high value Superfruit that could stimulate other local industries and could also function as a model in the ASEAN community.

\section{MATERIALS AND METHODS}

\section{Preparation of explants}

Young and healthy shoot explants were harvested from the olive plants grown at the Herbarium Unit of School of Biological Sciences, Universiti Sains Malaysia. The plants were previously obtained from the Malaysian Superfruit Valley, Perlis and were maintained under direct sunlight fertilised with general NPK fertilisers. The olive plants grown in the Malaysian Superfruit Valley are not matured to produce flowers and fruits for cultivar identification, hence is named as cv.1 and is yet to be identified.

\section{Explants surface sterilization}

The nodal explants (approximately $2-7 \mathrm{~cm}$ long) were soaked and brushed gently in $10 \%(\mathrm{v} / \mathrm{v})$ Sunlight ${ }^{\circledR}$ dishwashing solution with a few drops of Tween-20. The explants were then rinsed thoroughly under running tap water for approximately an $\mathrm{hr}$ before agitation in $70 \%(\mathrm{v} / \mathrm{v})$ ethanol for $2 \mathrm{~min}$. The explants were then treated in $30 \%(\mathrm{v} / \mathrm{v})$ Clorox $^{(\mathcal{C}}$ concentration at different durations $(7,8,9$ and 10 min). The explants were then rinsed with sterile distilled water and dried on sterile filter paper. Approximately $1.5 \mathrm{~cm}$ of nodal segments were excised and were transferred into a test tube containing MS (Murashige \& Skoog, 1962) basal salts and vitamins with $2 \%(\mathrm{w} / \mathrm{v})$ sucrose solidified with $0.8 \%(\mathrm{w} / \mathrm{v})$ plant agar (Duchefa, The Netherlands). All the explants were incubated at $16 / 8 \mathrm{hr}$ photoperiod under white fluorescent light (Philip TLD, $36 \mathrm{~W}, 150 \mu \mathrm{mol} \mathrm{m}^{-2} \mathrm{~s}^{-1}$ ) at $25 \pm 2^{\circ} \mathrm{C}$. The experiment consisted of 20 replicates, each containing two nodal segments per culture vessel. The percentage of explant contamination, necrosis and survival were assessed using the formulas below after 7 days of incubation.

$$
\begin{aligned}
& \text { Contamination rate }=\frac{\text { number of contaminated explants }}{\text { Total explants }} \times 100 \% \\
& \text { Necrosis rate }=\frac{\text { number of necrosis explants }}{\text { Total explants }} \times 100 \%
\end{aligned}
$$

Survival rate $=100 \%-$ contamination rate - necrosis rate

\section{Shoot induction in MS media with BAP and Zeatin}

The 7 days old sterile nodal explants were inoculated in MS media supplemented with different concentrations of BAP and Zeatin (0, 2.5, 5.0, 7.5 and $10.0 \mathrm{mg} / \mathrm{L})$. Media was prepared with MS basal salts and vitamins added with $2 \%(\mathrm{w} / \mathrm{v})$ sucrose and solidified with $0.8 \%(\mathrm{w} / \mathrm{v})$ plant agar (Duchefa, The Netherlands). Experiments consisted of seven replicates, each containing two explants inoculated per culture vessel. The percentage of shoot induction, average number of shoots induced per explant and the average length of induced shoots were evaluated after 21 days of culture.

\section{Data analysis}

All data were analysed using IBM SPSS Statistical 24 Software. Data were subjected to Oneway Analysis of Variance (ANOVA) followed by Duncan's Multiple Range Test with a significance 
level of $p \leq 0.05$. The highest average shoot length and shoot number of each plant growth regulator treatment were compared to the control treatment through independent sample T-test with the confidence level of $95 \%$.

\section{RESULTS AND DISCUSSION}

\section{Explant surface sterilization}

Surface sterilization of explant is a crucial step in plant tissue culture particularly to obtain sterile cultures. With reference to the results from the current study, the treatment of $30 \%$ Clorox $^{\circledR}$ for 8 min was found to be optimal for the survival of explants in comparison to the other five different exposure times (Table 1). This treatment had resulted in $85 \%$ survival rate of explants, similar to the $10 \mathrm{~min}$ treatment. Even though the duration of 9 min in the treatment of Clorox ${ }^{\odot}$ solution resulted in the highest survival rate $(87.5 \%), 8$ min treatment was still found to be optimal as the occurrence of browning of explants was observed to be lower. No necrosis was observed for all surface sterilization treatments.

Based on the report by Smith (2013), the seven days incubation period was reported to be adequate to assess potential contamination on sterilised explants as most contamination can be visible in culture within this period. Commercial bleach such as Clorox $^{\circledR}$ contains sodium hypochlorite, which is then converted into chlorine when dissolved in water. Chlorine functions to oxidise certain key enzymes and causes interference in the microbial metabolism and eliminates the growth of most fungus and bacteria (Siqueira et al., 1997). However, the exposure time and concentration of Clorox ${ }^{\circledR}$ treatments are dependent on the explant type and age. As for olive cultures, the cultivar type is also a factor to be considered, as high concentrations of Clorox ${ }^{\odot}$ or chlorine-based disinfectants can cause oxidation and burning to the explants (Afridi et al., 2015). Hence, the selection of disinfectants, their concentrations and the durations applied, are essential factors to be considered to optimize the elimination of contaminants while maintaining explant survival. In a previous study by Roussos and Pontikis (2002), the application of $10 \%(\mathrm{v} / \mathrm{v})$ of

Table 1. Effect of $30 \%$ Clorox concentration with different exposure time to obtain sterile nodal explants

\begin{tabular}{cccc}
\hline $\begin{array}{c}\text { Clorox } \\
\begin{array}{c}\text { Concentration } \\
(\% \mathrm{v} / \mathrm{v})\end{array}\end{array}$ & $\begin{array}{c}\text { Exposure } \\
\text { time } \\
(\mathrm{min})\end{array}$ & $\begin{array}{c}\text { Contamination } \\
\text { rate }(\%) \\
(\mathrm{A})\end{array}$ & $\begin{array}{c}\text { Survival } \\
\text { rate }(\%) \\
(100-\mathrm{A})\end{array}$ \\
\hline 30 & 7 & 32.5 & 67.5 \\
30 & 8 & 15 & 85 \\
30 & 9 & 12.5 & 87.5 \\
30 & 10 & 15 & 85 \\
\hline
\end{tabular}

$\mathrm{NaOCl}$ with three drops of Tween-20 for 10 min was found to be effective in the sterilisation of uninodal explants of the 'Koroneiki' olive tree. Anissa et al. (2011) on the other hand also reported that the treatment of commercial bleach containing $12 \%$ (v/v) $\mathrm{NaOCl}$ for 8 min on uninodal segment explants was found to be efficient for the cultivar of 'Oueslati'. Based on the report by Afridi et al. (2015), treatment of $50 \%(\mathrm{v} / \mathrm{v})$ Clorox $($ for $5 \mathrm{~min}$ on uninodal explants of the olive cultivar 'Uslu' resulted in the highest survival rate of $40 \%$ with lower occurrences of bacterial contamination. They also noted that longer treatment durations of more than 5 min with Clorox ${ }^{\odot}$ resulted in reduced survivability of explants due to burning (Afridi et al., 2015). Due to the difficulties in obtaining sterile cultures for olive explants, other reports incorporated the use of mercuric chloride $\left(\mathrm{HgCl}_{2}\right)$ in the surface sterilization step to further improve the rate of sterility in culture for different olive cultivars (Grigoriadou et al., 2002; Zacchini \& Agazio, 2004). Mercuric chloride is known to be an extremely toxic form of mercury and can cause severe poisoning to humans. In the current study, explant sterility was achieved via the use of the ethanol, sodium hypochlorite and Tween-20, without the use of $\mathrm{HgCl}_{2}$ which is deemed safer. These studies indicated the challenges in obtaining sterile cultures for olive and that different cultivars of olive require different treatments of surface sterilization protocols, as factors such as plant morphology and exposure to the environmental contaminants during explant harvesting can result in the survivability and sterility of explant in culture.

\section{The effects of BAP and Zeatin on multiple shoot induction}

With reference to the results from the current study, the treatment of $5.0 \mathrm{mg} / \mathrm{L}$ of BAP in MS media was found to be the optimal treatment for the induction of shoots for the olive explants in comparison to the other treatments of BAP and zeatin. MS media fortified with $5.0 \mathrm{mg} / \mathrm{L}$ of BAP produced the highest shoot induction rate $(100 \%)$, the highest average number of shoots per explant $(2.10 \pm 0.31)$ and the highest average length of shoot $(6.50 \pm 1.17 \mathrm{~mm})$ among the other BAP concentrations (Table 2). However, it is noteworthy that MS media supplemented with $2.5 \mathrm{mg} / \mathrm{L}$ of zeatin also produced maximum shoot induction rate $(100 \%)$ (Table 2). The morphology of shoots induced from the nodal explants from both BAP and zeatin treatments were observed to be different is shown in Figure 1 and Figure 2, respectively. Zeatin treatments were observed to induce shoots that were incomplete without visible leaf and shoot tip formation. It was also evident that there was a significant difference in terms of the average shoot length between treatments of $5.0 \mathrm{mg} / \mathrm{L}$ of BAP $(6.50$ 
Table 2. The percentage of shoot induction, shoot number and shoot length of the nodal explants of olive in single treatments of BAP and zeatin after 21 days of culture

\begin{tabular}{|c|c|c|c|c|}
\hline $\begin{array}{l}\text { Concentration } \\
\text { of BAP } \\
\text { (mg/L) }\end{array}$ & $\begin{array}{l}\text { Concentration } \\
\text { of Zeatin } \\
(\mathrm{mg} / \mathrm{L})\end{array}$ & $\begin{array}{c}\text { Percentage of } \\
\text { shoots induction } \\
(\%)\end{array}$ & $\begin{array}{c}\text { Average shoot } \\
\text { number }(\mathrm{N}) \\
(\mathrm{x} \pm \text { s.e. })\end{array}$ & $\begin{array}{l}\text { Average shoot } \\
\text { length }(\mathrm{cm}) \\
(x \pm \text { s.e. })\end{array}$ \\
\hline 0.0 & & 92 & $1.52 \pm 0.14 a b$ & $4.02 \pm 0.46 a b$ \\
\hline 2.5 & & 91 & $1.82 \pm 0.30 a b$ & $5.80 \pm 1.32 b c$ \\
\hline 5.0 & & 100 & $2.10 \pm 0.31 b$ & $6.50 \pm 1.17 \mathrm{c}^{*}$ \\
\hline 7.5 & & 90 & $1.20 \pm 0.33$ & $3.78 \pm 1.19 a b$ \\
\hline \multirow[t]{5}{*}{10.0} & & 90 & $1.50 \pm 0.43 a b$ & $3.85 \pm 1.55 a b$ \\
\hline & 2.5 & 100 & $1.67 \pm 0.19 a b$ & $3.13 \pm 0.30 a^{*}$ \\
\hline & 5.0 & 94 & $1.88 \pm 0.19 a b$ & $2.50 \pm 0.19 a$ \\
\hline & 7.5 & 93 & $1.64 \pm 0.17 \mathrm{ab}$ & $2.73 \pm 0.18 a$ \\
\hline & 10.0 & 90 & $1.60 \pm 0.22 a b$ & $2.50 \pm 0.31^{a}$ \\
\hline
\end{tabular}

Treatments with the same letter of the alphabet are not significantly different $(p<0.05)$. Treatments with * are significantly different from the control analysed through T-test. The measurement for the average shoot number and shoot length is based on 14 explants per treatment.

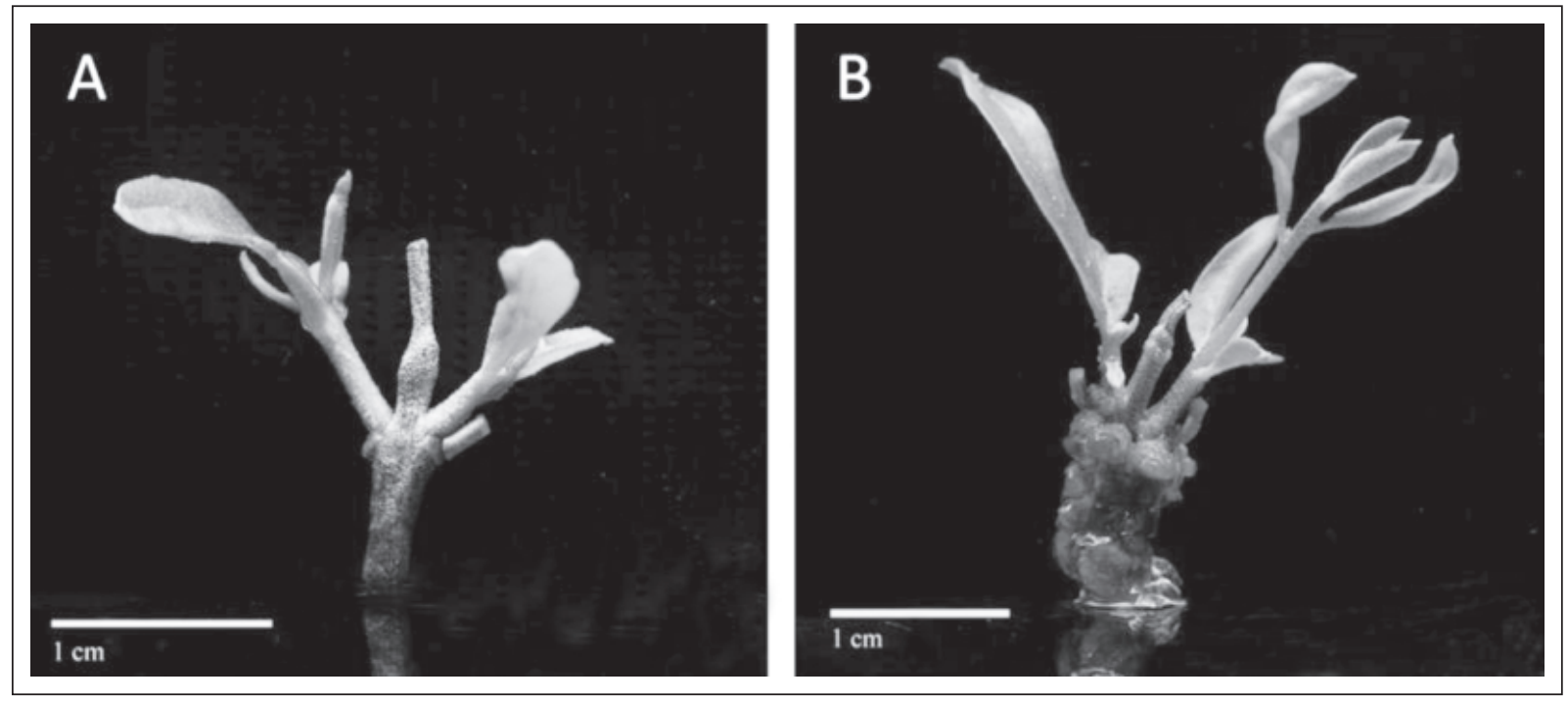

Fig. 1. Shoot induction from nodal explants of olive treated in (A) MS media (control) and (B) MS media supplemented with $5.0 \mathrm{mg} / \mathrm{L}$ BAP after 21 days of culture.

$\pm 1.17 \mathrm{~mm})$ and $2.5 \mathrm{mg} / \mathrm{L}$ of zeatin $(3.13 \pm 0.30 \mathrm{~mm})$, further indicating that BAP was more favourable in terms of shoot elongation than zeatin. However, a longer period of incubation may be required to further strengthen our findings.

Similar to our studies, García-Férriz et al. (2002) observed that the olive cultures from the cultivar of 'Arbequina' produced the highest shoot number in MS media supplemented with $5.0 \mathrm{mg} / \mathrm{L}$ BAP as compared to the other BAP concentrations. Grigoriadou et al. (2002) on the other hand, also reported that the increase in the treatments of BAP concentrations $(0 \mathrm{mg} / \mathrm{L}$ to $2.70 \mathrm{mg} / \mathrm{L})$ in Woody Plant Media resulted in increased shoot length ( 0 to 3.7 $\mathrm{cm}$ ) and proliferation rate (0 to 1.4) for Greek olive of the cultivar 'Chondrolia Chalkidikis'. Besides, Mangal et al. (2014) also reported that half-strength MS media supplemented with $2.0 \mathrm{mg} / \mathrm{L}$ BAP induced the highest rate of bud proliferation (56.25\%), while Airò et al. (2015) also highlighted that higher number of shoots was obtained in half-strength MS medium supplemented with $2 \mathrm{mg} / \mathrm{L}$ BAP. A study conducted by Seyhan and Özzambak (1994) showed that nodal explants treated with modified Rugini olive media supplemented with $2.0 \mathrm{mg} / \mathrm{L}$ of BAP induced the highest number of shoots for the olive cultivars of Memecik (15 shoots) and Domat (17 shoots). In this experiment, the growth of green callus was observed at the base of the nodal explants for the concentration of BAP ranged between 2.5 to $10.0 \mathrm{mg} / \mathrm{L}$ (Figure 1A), further indicating the possibility of shoot initiation from the callus. This observation is similar to the reports of Lambardi and Rugini (2003) and Fabbri et al. (2004) where the induction of thin shoots and abundant callus growth was induced in treatments of BAP. The formation of green callus at the base of 


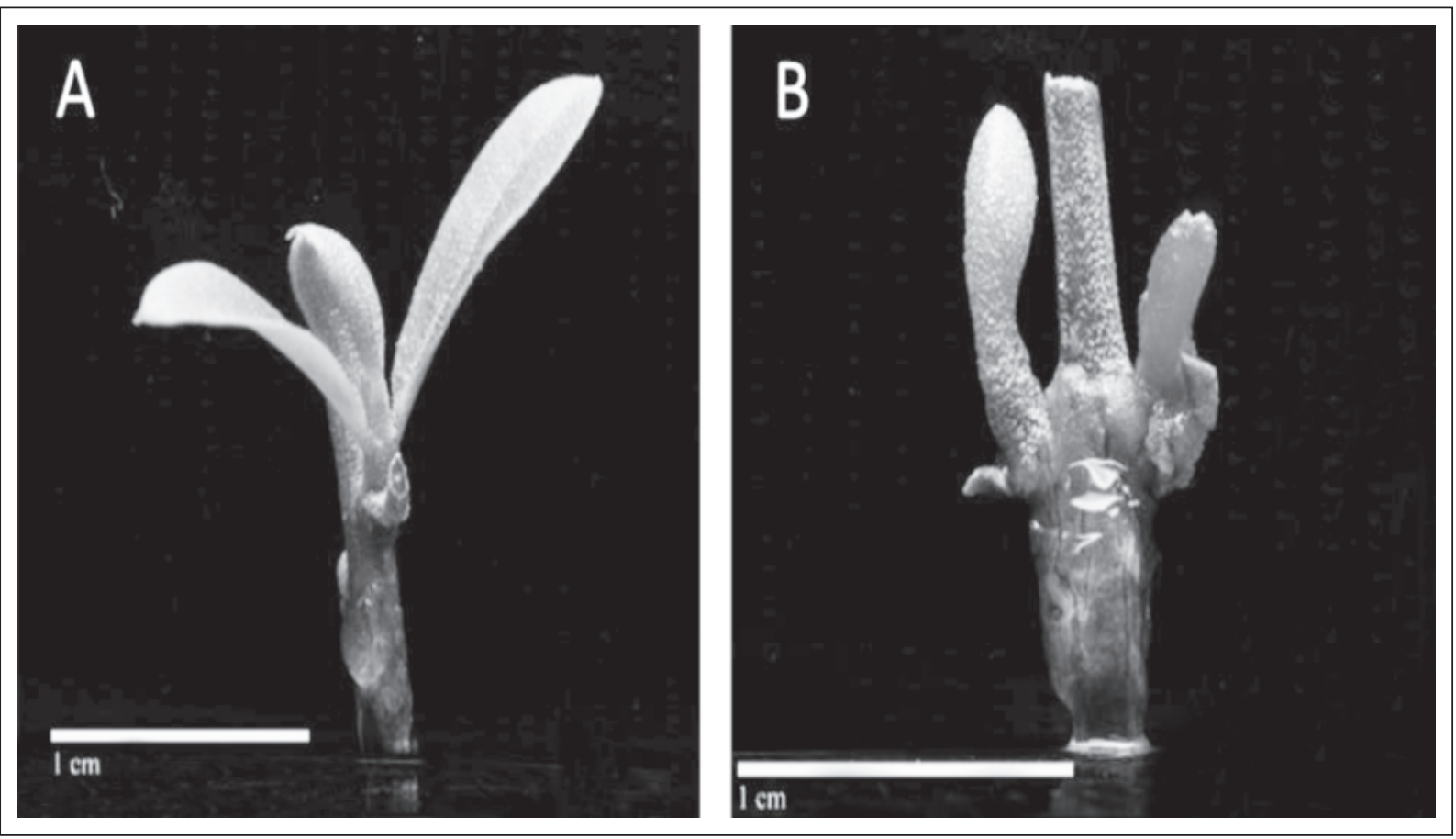

Fig. 2. Shoot induction from nodal explants of olive treated in (A) MS media (control) and (B) MS media supplemented with $2.5 \mathrm{mg} / \mathrm{L}$ zeatin after 21 days of culture.

the nodal explants induced in the BAP treatments were mostly due to two possible molecular mechanisms of callus inductions. They are the cytokinin-induced callus formation and the woundinduced callus formation (Ikeuchi et al., 2013). The mechanism for cytokinin-induced callus formation involves the upregulation of the AP2/ERF transcription factor ESR1 (ENHANCED SHOOT REGENERATION) and its possible homolog, ESR2 (Ikeuchi et al., 2013) that are linked to the cell cycle. In a study on Arabidopsis, wounded sites stimulate the expression of WOUND INDUCED DEDIFFERENTIATION (WIND 1 to 4) where the expression of the WIND genes initiates callus formation whereas its overexpression could induce the formation of somatic embryos (Iwase et al., 2011; Ikeuchi et al., 2013).

Previous studies however did report on the efficiency of zeatin in the induction of shoots from olive explants. Based on the work of Fabbri et al. (2004), it was evident that the addition of 1 to 4 $\mathrm{mg} / \mathrm{L}$ of zeatin was suitable for shoot proliferation for most olive cultivars such as the cultivars of 'Carolea', 'Frantoio', 'FS-17', 'Meski', 'Moraiolo', and 'Nocellara Etnea'. Similarly, Lambardi et al. (2013) also suggested that the addition of 1 to 4 $\mathrm{mg} / \mathrm{L}$ zeatin in culture media was suitable for shoot proliferation of most commercial olive cultivars. Chaari Rkhis et al. (2011) reported that 'Oueslati' olive cultures treated in MS media supplemented with $4.0 \mathrm{mg} / \mathrm{L}$ zeatin produced higher number of nodes with the multiplication rate of $4.1 \pm 1.6$, whereas Chaari et al. (2002) noted that the treatment of $1 \mathrm{mg} / \mathrm{L}$ zeatin resulted in the highest length of shoot elongation $(17.08 \mathrm{~cm})$ with the multiplication rates of 11 for the olive cultivar of Meski. Similar to our study, the supplementation of $2.5 \mathrm{mg} / \mathrm{L}$ of zeatin in MS media (within the range of 1 to $4 \mathrm{mg} / \mathrm{L}$ as previously reported) resulted in higher shoot number $(1.83 \pm$ $0.11)$ and shoot length $(3.13 \pm 0.30 \mathrm{~mm})$ in comparison to the treatments above $5 \mathrm{mg} / \mathrm{L}$. Previous reports have also utilised low concentrations of zeatin in different growth media for the induction of multiple shoots in olive. Both olive cultivars of Moraiolo and Dolce Agogia cultured in modified OM media supplemented with $2.0 \mathrm{mg} / \mathrm{L}$ of zeatin resulted in optimal viability and growth (Micheli et al., 2010). Furthermore, Farooq et al. (2017) also reported that nodal explants of olive cv. Frontio, Earlik, and Gemlik produced the highest multiplication rate in OM media supplemented with $13.6 \mu \mathrm{M}(2.98 \mathrm{mg} / \mathrm{L})$ of zeatin producing mean shoot number of 2 and the highest shoot length of $34.0 \mathrm{~mm}$. However, based on the reports from the current study, it was evident that the treatments of BAP induced longer shoot length for the initiated shoots in culture in comparison to the zeatin supplementation.

Even though BAP and zeatin are categorized as cytokinins, the requirement of both plant growth regulators in plants differ according to the type of plant, culture and maturity of the tissues in which the explants were obtained (George et al., 2007). Based on George et al. (2007), the mode of action of BAP was found to be slightly different from zeatin. 
BAP, also known as BA, generally promotes axillary bud proliferation while zeatin on the other hand stimulates growth of the main shoots resulting in slight increase of lateral buds sprouting (George et al., 2007). This is in parallel to our findings where BAP treatments were found to induced higher number of shoots in comparison to the same concentration treatments of zeatin.

Cytokinin levels in plants are not only regulated for the maintenance of cell division cycle but also to promote the transition of cell division cycle from undifferentiated stem cells to further differentiate (Mazid et al., 2011). Cytokinin was found to induce shoot meristem formation from unorganized growing cells, further indicating that cytokinin functions beyond the maintenance cell cycle (Skoog \& Miller, 1957). Generally, plant responses to cytokinin involve two-component systems, histidine kinase membrane bound receptors and multiple phosphorelay signaling components. Werner et al. (2001) and Werner et al. (2003) demonstrated the changes in cell division of Arabidopsis thaliana via histological diagrams. In their study, cytokinin was found to stimulate cell division at the shoot apical meristem and that the transgenic Arabidopsis thaliana, with lower content of cytokinin, showed fewer cells occupying the space between the central zone and the peripheral zone of lateral organ formation in comparison to the wild type. Werner et al. (2003) also reported that a reduction in the cytokinin levels resulted in reduced diameter and height of meristem coupled with lower number of meristem cells in the shoot apical.

Cytokinin are perceived by histidine kinases generating signals and is transferred as a form of phosphoryl group to the response regulators in the nucleus via histidine-containing phosphotransmitter in the cytoplasm (Hwang \& Sheen, 2001). Auer et al. (1999) reported that development response of an explant may be affected by the hormone uptake, metabolism, and transport within the explants. Supplementation of BAP in cultures was found to also induce high expression of cell-division-related genes such as the cycline D2 (CYCD), histone H4 (His4), proliferating cell nuclear antigen (PCNA) and cyclin-dependent kinase B (CDKB) (Ma et al., 2016). The His4 and PCNA genes are involved in RNA and DNA replication at G1 and S phase, while $\mathrm{CDKB}$ are involved in the G2-M phase of cell cycle. These cell-division-related genes linked to the cytokinin signaling pathway are potentially responsible for the development of shoot apical meristem and axillary meristem, as previously reported for Pisum sativum (Stafstrom \& Sussex, 1992) and sorghum (Kebrom et al., 2010a, 2010b). BAP treatments were also found to increase the transcript level of CK synthesis gene isopentenyl transferase (IPT) resulting in increased endogenous cytokinin content, isopentenyladenosine (iPA) that elevates the levels of transcript for cytokinin signalling pathway receptors, histidine kinase and response regulators (Ma et al., 2016; Panda et al., 2018). Therefore, it is possible that even though both plant growth regulators are relatable and are under the same category, the concentration of these cytokinins remaining in the plant may affect the way it induces the plant development causing the same concentration of cytokinin to produce different outcomes.

\section{CONCLUSION}

In this study, the optimal surface sterilisation protocol for the nodal explants is in the treatment of 2 min agitation in $70 \%(\mathrm{v} / \mathrm{v})$ ethanol and $8 \mathrm{~min}$ agitation of $30 \%(\mathrm{v} / \mathrm{v})$ Clorox $^{\odot}$. The supplementation of $5.0 \mathrm{mg} / \mathrm{L}$ of BAP in MS medium was found to be optimal for the induction of axillary shoots and shoot elongation for nodal explant of Olea europaea cv.1. Future work includes in depth optimization of multiple shoot induction and acclimatization for the propagation of olive plants. The current study also highlights the potential of tissue culture technology in the mass propagation of olives for the production of high-quality plant stocks suitable for olive farming in Malaysia.

\section{ACKNOWLEDGEMENT}

The authors would like to thank the Malaysia Superfruit Valley, Perlis for the supply of olive plants and their support towards this project. They would also like to thank the Malaysian Economic Planning Unit, Prime Minister's Department for funding the project (304/PBIOLOGI /6501099/U12) and University Sains Malaysia for the research support.

\section{REFERENCES}

Afridi, M.I., Ali, N., Shinwari, K.I., Hassan, N.A., Butt, A.A., Shah, A., Salman, S. \& Muhammad, A. 2015. Optimization of aseptic conditions for micropropagation of olive (Olea europaea L.) Cultivar Uslu. Journal of Bio-Molecular Sciences, 3(1): 35-43.

Airò, M., Giardina, G. \& Giovino, A. 2015. In vitro propagation of 'Frangipani'. Acta Horticulturae, 1083: 545-548.

Ali, A., Ahmad, T., Abbasi, N.A. \& Hafiz, I.A. 2009. Effect of different media and growth regulators on in vitro shoot proliferation of olive cultivar 'Moraiolo'. Pakistan Journal of Botany, 41: 783795. 
Anissa, C.R., Mohamed, M., Noureddine, D. \& Alvaro, S. 2011. Micropropagation of olive tree Olea europaea L. 'Oueslati'. Turkish Journal of Agriculture and Forestry, 35: 403-412.

Attum, B., Hafiz, S., Malik, A. \& Shamoon, Z. 2020. Cultural competence in the care of Muslim patients and their families. StatPearls Publishing, United State of America.

Auer, C.A., Motyka, V., Bøezinová, A. \& Kamínek, M. 1999. Endogenous cytokinin accumulation and cytokinin oxidase activity during shoot organogenesis of Petunia hybrida. Physiologia Plantarum, 105(1): 141-147.

Bahrami, M.K., Motallebi Azar, A. \& Dadpour, M.R. 2010. Influence of thidiazuron in direct shoot regeneration from segments of in vitro leaves, and axillary and apical buds of olive (Olea europaea). Acta Horticulturae, 884: 383-390.

Beauchamp, G.K., Keast, R.S., Morel, D., Lin, J., Pika, J., Han, Q., Lee, C.H., Smith, A.B. \& Breslin, P.A. 2005. Phytochemistry: Ibuprofen-like activity in extra-virgin olive oil. Nature, 437: 45-46.

Besnard, G., Green, P.S. \& Bervillé, A. 2002. The genus Olea: molecular approaches of its structure and relationships to other Oleaceae. Acta Botanica Gallica, 149(1): 49-66.

Bhatia, S. 2015. Plant tissue culture. In: Modern Applications of Plant Biotechnology in Pharmaceutical Sciences. S. Bhatia, K. Sharma, R. Dahiya and T. Bera (Eds.). pp. 31-107.

Binet, M.N., Lemoine, M.C., Martin, C., Chambon, C. \& Gianinazzi, S. 2007. Micropropagation of olive (Olea europaea L.) and application of mycorrhiza to improve plantlet establishment. In vitro Cellular \& Developmental Biology - Plant, 43(5): 473-478.

Cañas, L.A. 1988. In vitro culture of the olive tree (Olea europaea L.): present aspects and prospects. Bulletin de La Société Botanique de France. Lettres Botaniques, 135(3): 263-277.

Chaari Rkhis, A., Maalej, M., Drira, N. \& Standardi, A. 2011. Micropropagation of olive tree Olea europaea L. 'Oueslati'. Turkish Journal of Agriculture and Forestry, 35(4): 403-412.

Chaari, A., Chelli, A., Maalej, M. \& Drira, N. 2002. Meski olive variety propagated by tissue culture. Acta Horticulturae, 586: 871-874.

Fabbri, A., Bartolini, G., Lambardi, M. \& Kailis, S.K. 2004. Olive Propagation Manual. CSIRO Publishing, Australia. 164 pp.

Farooq, Q.U.A., Fatima, A., Murtaza, N. \& Hussain Ferdosi, F. 2017. In vitro propagation of olive cultivars 'Frontio', 'Earlik', 'Gemlik'. Acta Horticulturae, 1152: 249-256.

García-Férriz, L., Ghorbel, R., Ybarra, M., Marì, A., Belaj, A. \& Trujillo, I. 2002. Micropropagation from adult olive trees. Acta Horticulturae, 586: $879-882$
George, E.F., Hall, M.A. \& Klerk, G.-J.D. 2007. Plant propagation by tissue culture. Springer, The Netherland. 502 pp.

Grigoriadou, K., Vasilakakis, M. \& Eleftheriou, E.P. 2002. In vitro propagation of the Greek olive cultivar 'Chondrolia Chalkidikis'. Plant Cell, Tissue and Organ Culture, 71(1): 47-54.

Haris Omar, S. 2010. Oleuropein in olive and its pharmacological effects. Scientia Pharmaceutica, 78(2): 133-154.

Kebrom, T.H., Brutnell, T.P. \& Finlayson, S.A. 2010a. Suppression of sorghum axillary bud outgrowth by shade, phyB and defoliation signalling pathways. Plant, Cell \& Environment, 33: 4858.

Kebrom, T.H., Brutnell, T.P., Hays, D.B. \& Finlayson, S.A. 2010b. Vegetative axillary bud dormancy induced by shade and defoliation signals in the grasses. Plant Signaling \& Behavior, 5: 317-319.

Hwang, I. \& Sheen, J. 2001. Two-component circuitry in Arabidopsis cytokinin signal transduction. Nature, 413: 383-389.

Ikeuchi, M., Sugimoto, K. \& Iwase, A. 2013. Plant callus: mechanisms of induction and repression. The Plant Cell, 25(9): 3159-3173.

Iwase, A., Mitsuda, N., Koyama, T., Hiratsu, K., Kojima, M., Arai, T., Inoue, Y., Seki, M., Sakakibara, H., Sugimoto, K. \& Ohme-Takagi, M. 2011. The AP2/ERF transcription factor WIND1 controls cell dedifferentiation in Arabidopsis. Current Biology, 21: 508-514.

Lambardi, M. \& Rugini, E. 2003. Micropropagation of olive (Olea europaea L.). In: Micropropagation of Woody Trees and Fruits. S.M. Jain and K. Ishii (Eds.). Springer, Netherlands. pp. 621646.

Lambardi, M., Ozudogru, E.A. \& Roncasaglia, R. 2013. In vitro propagation of olive (Olea europaea L.) by nodal segmentation of elongated shoots. In: Protocols for micropropagation of selected economicallyimportant horticultural plants. M. Lambardi, E.A. Ozudogru and S.M. Jain (Eds.). Humana Press, United States of America. pp. 33-44.

Ma, X., Xu, Q., Meyer, W.A. \& Huang, B. 2016. Hormone regulation of rhizome development in tall fescue (Festuca arundinacea) associated with proteomic changes controlling respiratory and amino acid metabolism. Annals of Botany, 118(3): 481-494.

Mangal, M., Sharma, D., Sharma, M. \& Kumar, S. 2014. In vitro regeneration in olive (Olea europaea L.) cv, 'Frontoio' from nodal segments. Indian Journal of Experimental Biology, 52: 912-916. 
Mazid, M., Khan, T.A. \& Mohammad, F. 2011. Cytokinins, A classical multifaceted hormone in plant system. Journal of Stress Physiology \& Biochemistry, 7(4): 347-368.

Micheli, M., Standardi, A., El Behi, A.W., Zakhour, D. \& Yasin, M. 2010. In vitro proliferation of olive ('Dolce Agogia' and 'Moraiolo'): effect of different cytokinins. Acta Horticulturae, 884: 587-590.

Murashige, T. \& Skoog, F. 1962. A revised medium for rapid growth and bio-assays with tobacco tissue cultures. Physiologia Plantarum, 15(3): 473-497.

Panda, B.B., Sekhar, S., Dash, S.K., Behera, L. \& Shaw, B.P. 2018. Biochemical and molecular characterisation of exogenous cytokinin application on grain filling in rice. BMC Plant Biology, 18(1): 89.

Peixe, A., Raposo, A., Lourenço, R., Cardoso, H. \& Macedo, E. 2007. Coconut water and BAP successfully replaced zeatin in olive (Olea europaea L.) micropropagation. Scientia Horticulturae, 113(1): 1-7.

Peyrot des Gachons, C., Uchida, K., Bryant, B., Shima, A., Sperry, J.B., Dankulich- Nagrudny, L., Tominaga, M., Smith, A.B.III, Beauchamp, G.K. \& Breslin, P.A.S. 2011. Unusual pungency from extra-virgin olive oil is attributable to restricted spatial expression of the receptor of oleocanthal. The Journal of Neuroscience, 31(3): 999-1009.

Roussos, P.A. \& Pontikis, C.A. 2002. In vitro propagation of olive (Olea europaea L.) cv. Koroneiki. Plant Growth Regulation, 37: 295 304.

Rugini, E. 1981. Propagazione in vitro di una cultivar di olivo (Olea europaea L.). Valutazione di varie citochinine ed auxine. Atti congresso su "Fitofarmaci in agricoltura". 171-180.

Rugini, E. 1984. In vitro propagation of some olive (Olea europaea sativa L.) cultivars with different root-ability, and medium development using analytical data from developing shoots and embryos. Scientia Horticulturae, 24: 123-134.

Schwingshackl, L. \& Hoffmann, G. 2014. Monounsaturated fatty acids, olive oil and health status: a systematic review and meta-analysis of cohort studies. Lipids in Health and Disease, 13(1): 154.

Siqueira, J.F., Jr, Machado, A.G., Silveira, R.M., Lopes, H.P. \& de Uzeda, M. 1997. Evaluation of the effectiveness of sodium hypochlorite used with three irrigation methods in the elimination of Enterococcus faecalis from the root canal, in vitro. International Endodontic Journal, 300(4): 279-282.
Skoog, F. \& Miller, C.O. 1957. Chemical regulation of growth and organ formation in plant tissues cultured in vitro. Symposia of the Society of Experimental Biology, 11: 118-131.

Smith, R. 2013. Plant tissue culture. 3rd Ed. Academic Press, United Kingdom. 208 pp.

Stafstrom, J.P. \& Sussex, I.M. 1992. Expression of a ribosomal protein gene in axillary buds of pea seedlings. Plant Physiology, 100: 1494-1502.

Tripoli, E., Giammanco, M., Tabacchi, G., Di Majo, D., Giammanco, S. \& La Guardia, M. 2005. The phenolic compounds of olive oil: structure, biological activity and beneficial effects on human health. Nutrition Research Reviews, 18(1): 98-112.

Uylaşer, V. \& Yildiz, G. 2014. The historical development and nutritional importance of olive and olive oil constituted an important part of the Mediterranean diet. Critical Reviews in Food Science and Nutrition, 54(8): 1092-1101.

Visioli, F., Bogani, P. \& Galli, C. 2006. Healthful properties of olive oil minor components, in olive oil. In: Olive Oil. D. Boskou (Ed.). Academic Press and AOCS Press, United States of America. pp. 173-190.

Visioli, F., Galli, C., Galli, G. \& Caruso, D. 2002. Biological activities and metabolic fate of olive oil phenols. European Journal of Lipid Science and Technology, 104: 677-684.

Werner, T., Motyka, V., Laucou, V., Smets, R., Onckelen, H.V. \& Schmülling, T. 2003. Cytokinin deficient transgenic Arabidopsis plants show multiple developmental alterations indicating opposite functions of cytokinins in the regulation of shoot and root meristem activity. Plant Cell, 15: 2532-2550.

Werner, T., Motyka, V., Strnad, M. \& Schmülling, T. 2001. Regulation of plant growth by cytokinin. Proceedings of the National Academy of Sciences of the United States of America, 98(18): 10487-10492.

Wiesman, Z. 2009. Desert olive oil cultivation. 1st Ed. Academic Press, United States of America. 416 pp.

Zacchini, M. \& De Agazio, M. 2004. Micropropagation of a local olive cultivar for germplasm preservation. Biologia Plantarum, 48(4): 589-592. 